\title{
Additives on in vitro ruminal fermentation characteristics of rice straw
}

\section{Vanessa Peripolli ${ }^{*}$, Júlio Otávio Jardim Barcellos ${ }^{2}$, Ênio Rosa Prates ${ }^{2}$, Concepta McManus ${ }^{3}$, Laion Antunes Stella ${ }^{1}$, Cláudia Medeiros Camargo ${ }^{4}$, João Batista Gonçalves Costa $\mathrm{Jr}^{5}$, Cimélio Bayer $^{6}$}

\author{
${ }^{1}$ Universidade Federal do Rio Grande do Sul, Programa de Pós-graduação em Zootecnia, Porto Alegre, RS, Brazil. \\ ${ }^{2}$ Universidade Federal do Rio Grande do Sul, Faculdade de Agronomia, Departamento de Zootecnia, Porto Alegre, RS, Brazil. \\ ${ }^{3}$ Universidade de Brasília, Instituto de Ciências Biológicas, Brasília, DF, Brazil. \\ ${ }^{4}$ Universidade Federal de Pelotas, Pelotas, RS, Brazil. \\ ${ }^{5}$ Faculdades Associadas de Uberaba, Uberaba, MG, Brazil. \\ ${ }^{6}$ Universidade Federal do Rio Grande do Sul, Faculdade de Agronomia, Departamento de Solos, Porto Alegre, RS, Brazil.
}

\begin{abstract}
The objective of this study was to evaluate the effects of mineral and protein-energy (MPES), exogenous fibrolytic enzyme supplements (ES), combination of MPES + ES, and straw without supplement (WS) on digestibility, fermentation kinetic parameters, cumulative gas production, methane, $\mathrm{CO}_{2}$ production, and volatile fatty acid concentration of rice straw of low and high nutritional value, estimated by in vitro techniques. The experimental design was randomized and factorial $2 \times 4$ : two straws (low and high nutritional value) incubated with four supplements (MPES, ES, MPES + ES, and WS) and their interactions. Four experimental periods were used, totaling four replications per treatment over time. Data were analyzed by PROC MIXED of SAS. The in vitro dry matter and organic matter digestibilities of the rice straw with high nutritional value was improved by MPES, while the combination of MPES + ES supplements inhibited the digestibility of this straw. Dietary carbohydrate and nitrogen increased through MPES and MPES + ES supplements resulted in an increase in $\mathrm{NH}_{3}-\mathrm{N}$ concentration and a decrease in $\mathrm{CO}_{2}$ production due to the microbial mass formation. However, this increase was not enough to improve organic matter degradability parameters, cummulative gas production, gas production kinetics, and acetate:propionate ratio and reduce methane emissions. The straw with high nutritional value showed greater content of nitrogen fraction a, effective degradability, cummulative gas production, and methane and $\mathrm{CO}_{2}$ productions comparing with low-nutritional value straw. The use of MPES and MPES + ES supplements can be used as strategy to mitigate $\mathrm{CO}_{2}$ in ruminant production systems that use rice straw.
\end{abstract}

Key Words: digestibility, digestion kinetics, fatty acid, gas production, methane

\section{Introduction}

Rice is the second most cultivated cereal worldwide (FAO, 2016). Therefore, for each ton of rice grain harvested, one ton of straw remains in the field (Doyle et al., 1986). Despite the low nutritional value of rice straw due to its high silica content, low ruminal degradation of carbohydrates, and low nitrogen content, when stored in bales, it presents significant potential for strategic use in critical periods of

Received: July 26, 2016

Accepted: November 6, 2016

*Corresponding author: vanessa.peripolli@hotmail.com

http://dx.doi.org/10.1590/S1806-92902017000300009

How to cite: Peripolli, V.; Barcellos, J. O. J.; Prates, E. R.; McManus, C.; Stella, L. A.; Camargo, C. M.; Costa Jr, J. B. G. and Bayer, C. 2017. Additives on in vitro ruminal fermentation characteristics of rice straw. Revista Brasileira de Zootecnia 46(3):240-250

Copyright (C) 2017 Sociedade Brasileira de Zootecnia. This is an Open Access article distributed under the terms of the Creative Commons Attribution License (http://creativecommons.org/licenses/by/4.0/), which permits unrestricted use, distribution, and reproduction in any medium, provided the original work is properly cited. food availability or in ruminant production systems with low nutrient requirements.

Technologies to increase the use of low-quality feeds, such as rice straw, consist in optimizing nutrient availability for the ruminal fermentation, ensuring no deficiency of nutrients to the microorganisms. Increased bacterial growth may result in increased extraction, through fermentation, of the roughage carbohydrate energy and, as a result, microbial cells synthesized in the rumen are available for amino acid digestion and absorption in the intestine (Leng, 1990).

This nutrient availability optimization in cattle fed rice straw may be achieved with mineral and protein-energy supplementation aiming to improve forage digestibility to maximize its intake (Barbosa et al., 2007), meeting animal requirements for maintenance and moderate weight gain (Lima, 2002). Furthermore, this supplementation increases the ruminal ammonia nitrogen concentration and meets the requirements of the ruminal microorganisms, allowing maximum fermentation rates (Fike et al., 1995). 
Additionally, the increase in the metabolizable protein availability and the increase in the absorbed protein:energy ratio reduced the metabolic heat production, promoting greater intake and raising the gain rates (Leng, 1990; Poppi and McLennan, 1995).

On the other hand, supplementation with feed of low nutritional value, with exogenous fibrolytic enzymes, aims to increase nutrient use and animal production efficiency (Nsereko et al., 2000; Beauchemin et al., 2003) and reduce the fecal output. These enzymes potentiate the degradation of fibrous polysaccharides togheter with the enzymes produced by the rumen microorganisms, stimulating total digestion and degradation rate, thus improving the digestibility of fibrous feeds (Newbold, 1997).

The hypothesis that the improvement of the rice straw in vitro fermentation process may be achieved by using additives was investigated. Therefore, the objective of this study was to evaluate, through in vitro techniques, the effects of mineral and protein-energy and exogenous fibrolytic enzyme supplements on digestibility, fermentation parameters and kinetics, maximum gas production, methane $\left(\mathrm{CH}_{4}\right)$ and carbon dioxide $\left(\mathrm{CO}_{2}\right)$ production, and volatile fatty acid concentration in rice straw.

\section{Material and Methods}

Animal care procedures throughout the study followed protocols approved by the Ethics Committee for Animal Use (ECAU) of the Universidade Federal do Rio Grande do Sul, number 18442/2010.

Two straws (low and high nutritional value) were incubated in vitro without supplementation (WS), with mineral and protein-energy supplement (MPES), with exogenous fibrolytic enzymes supplement (ES), and with the combination of the two supplements (MPES + ES) (Table 1). Four experimental periods were used, totaling four treatment replications. Duplicate bottles were also included in each run as blanks.

The mineral and energy-protein supplement used was commercially available and prepared in compliance with the nutritional standards of the NRC (1996) for beef cattle, whose daily intake recommendation is $50 \mathrm{~g}$ $100 \mathrm{~kg}^{-1}$ body weight, composed of non-protein nitrogen source, macro and micro minerals, cottonseed and soybean meal, and wheat bran. The enzyme supplement was a commercially available source of xylanase, whose daily intake recommendation is $15 \mathrm{~g} \mathrm{head}^{-1}$, consisting of corn distillers' dried grains with solubles, plant protein products, Yucca schidigera plant extract, and dried Trichoderma longibrachiatum fermentation extract (Alltech Inc.).

The straw rice intake of $100 \mathrm{~g} \mathrm{~kg}^{-1}$ of body weight was considered.

The in vitro digestibility was determined by the twostage digestion technique proposed by Tilley and Terry (1963). Ruminal inoculum was collected from two fasting Texel sheep with an average weight of $60 \mathrm{~kg}$ adapted for 10 days to a diet based on alfalfa hay. Two hours after morning feed, rumen fluid and part of the rumen solid material were obtained to collect microorganisms adhered to the substrate. All collected material was homogenized in a blender at a ratio of $1: 1$ (solid:liquid portion) and filtered through four layers of gauze adding $\mathrm{CO}_{2}$.

In vitro organic matter digestibility (IVOMD) was calculated by the difference between the incubated and undigested organic matter (OM) present in crucibles (Goering and Van Soest, 1970).

Table 1 - Chemical composition and in vitro organic matter digestibility (IVOMD) of rice straw and mineral and protein-energy (MPES) and enzyme (ES) supplements used in the experimental diets

\begin{tabular}{|c|c|c|c|c|}
\hline Chemical composition ( $\mathrm{g} \mathrm{kg}^{-1}$ of dry matter) & High-nutritional value straw & Low-nutritional value straw & $\mathrm{MPES}^{1}$ & ES \\
\hline Dry matter ${ }^{2}$ & 873 & 915 & 927 & 915 \\
\hline Organic matter ${ }^{2}$ & 831 & 828 & 400 & 955 \\
\hline Crude protein ${ }^{2}$ & 44.7 & 37.4 & 398 & 240 \\
\hline Neutral detergent fiber ${ }^{3}$ & 732 & 781 & 196 & 317 \\
\hline Acid detergent fiber ${ }^{4}$ & 424 & 469 & 69.8 & 130 \\
\hline Cellulose $^{5}$ & 393 & 435 & 45.3 & 90.7 \\
\hline Hemicellulose ${ }^{5}$ & 307 & 302 & 126 & 186 \\
\hline Lignin $^{5}$ & 28.0 & 34.4 & 24.5 & 39.6 \\
\hline Silica $^{5}$ & 95.9 & 126 & - & - \\
\hline IVOMD & 529 & 424 & 653 & 765 \\
\hline
\end{tabular}

${ }^{1}$ Each kg contains: $60 \mathrm{~g}$ calcium; $30 \mathrm{~g}$ phosphorus; $14 \mathrm{~g}$ sulfur; $74 \mathrm{~g}$ sodium; $0.21 \mathrm{~g}$ manganese; $1.3 \mathrm{~g}$ zinc; $0.06 \mathrm{~g}$ cobalt; $0.12 \mathrm{~g}$ copper; $0.02 \mathrm{~g}$ iodine; $0.009 \mathrm{~g}$ selenium; $0.28 \mathrm{~g}$ fluorine; $330 \mathrm{~g}$ non-protein nitrogen; and $220 \mathrm{~g}$ total digestible nutrients.

${ }^{2}$ Determined according to AOAC (1975).

${ }^{3}$ Not assayed with stable amylase expressed exclusive of residual ash acid.

${ }^{4}$ Expressed inclusive of residual ash.

${ }^{5}$ Determined according to Van Soest et al. (1991) but with a modification to determine silica, in which the residue was burned in a muffle furnace at $550{ }^{\circ} \mathrm{C}$ overnight. 
In vitro cumulative gas production was obtained through the Theodorou et al. (1994) methodology modified by Mauricio et al. (1999), using a pressure transducer data logger (PDL 200 LANA/SCENE USP, Piracicaba/SP, Brazil) connected to a three-output valve. The first output was connected to the pressure transducer, the second to the needle (no. 22) to be inserted into the bottle stopper, and the third to a plastic syringe to measure the volume. Ruminal inoculum was obtained as described previously. The bottles were sealed with rubber stoppers and aluminum rings. In each experimental period, two bottles per treatment and per time were incubated, totaling 224 bottles plus the blank bottles (two blanks per incubation time, totaling 28 bottles). Four experimental periods were used, totaling four replications per treatment over time.

Pressure and volume of gas were measured at $0,1,3,6$, $9,12,18,24,30,36,48,60,72$, and 96 h post-incubation. Gas production was expressed in $\mathrm{mL}$ of gas produced per gram of organic matter incubated.

For degradation rate adjustment, gas production data were fitted using a bicompartimental model (Schofield et al., 1994): $\mathrm{V}(\mathrm{t})=\mathrm{A} /(1+\exp \times(2-4 \times \mathrm{B} \times(\mathrm{T}-\mathrm{C})))-1$ $+\mathrm{D} /(1+\exp (2-4 \times \mathrm{E} \times(\mathrm{T}-\mathrm{F})))-1$, in which $\mathrm{V}(\mathrm{t})=$ cumulative gas production at time $\mathrm{t}\left(\mathrm{mL} \mathrm{g}^{-1} \mathrm{OM}\right) ; \mathrm{A}=$ maximal gas production of the rapid fermentation fraction $(\mathrm{mL}) ; \mathrm{B}=$ fermentation rate of $\mathrm{A}(\mathrm{h}) ; \mathrm{C}=$ lag time of the fraction $\mathrm{A}(\mathrm{h}) ; \mathrm{D}=$ maximal gas production of the slow fermentation fraction $(\mathrm{mL}) ; \mathrm{E}=$ fermentation rate of $\mathrm{D}(\mathrm{h})$; $\mathrm{F}=$ lag time of the fraction $\mathrm{D}(\mathrm{h})$; and $\mathrm{T}=$ incubation time (h). The model parameters were estimated by interactive Marquardt method inserted into the NLIN procedure of SAS (Statistical Analysis System, version 9.3).

The partition factor (PF) was determined according to Makkar (2004): FP = mg OM truly degraded/mL gases. For this calculation, we considered $36 \mathrm{~h}$ of incubation (time in which half of the maximal gas production was produced by treatments).

At $6,12,24,48,72$, and $96 \mathrm{~h}$, the fermentation was stopped and the $\mathrm{pH}$ measurements were performed immediately. Subsequently, the contents of the bottles were filtered through a sintered-glass crucible of coarse porosity (100 to $160 \mu \mathrm{m})$. Crucible containing residue from the filtration was oven-heated at $105^{\circ} \mathrm{C}$ for $12 \mathrm{~h}$, weighed, resulting in a moisture-free residue, and subsequently heated at $450{ }^{\circ} \mathrm{C}$ for $5 \mathrm{~h}$. In vitro organic matter degradability was calculated by the difference between the incubated and undigested organic matter present in crucibles (Goering and Van Soest, 1970).

To study the ruminal degradability kinetics, the degradability obtained at different times was adjusted using the McDonald (1981) model: $\mathrm{Yt}=\mathrm{a}+\mathrm{b}(1-\exp -\mathrm{c}(\mathrm{t}-\mathrm{to}))$, in which $\mathrm{Yt}=$ losses for degradation after $\mathrm{t}$ hours; $\mathrm{a}=$ immediately solubilized substrate; $b=$ insoluble material, but potentially degradable; $a+b=$ potential degradability; $\mathrm{c}=$ degradation rate of $\mathrm{b} ; \mathrm{t}=$ incubation time $(\mathrm{h})$; and to $=$ lag time. The effective degradability (ED) was calculated using the equation proposed by Ørskov and McDonald (1979): $\mathrm{ED}=\mathrm{a}+[(\mathrm{b} \times \mathrm{c}) /(\mathrm{c}+\mathrm{k})] \exp (-(\mathrm{c}+\mathrm{k}) \mathrm{t})$, in which $\mathrm{a}, \mathrm{b}, \mathrm{c}$, and $\mathrm{t}$ followed previous definitions and $\mathrm{k}=$ ruminal outflow rates of 0.02 or $0.05 \mathrm{~h}^{-1}$.

At these same times, two aliquots of $5 \mathrm{~mL}$ of the filtrate were collected, one for volatile fatty acid and another for ammonia nitrogen $\left(\mathrm{NH}_{3}-\mathrm{N}\right)$ determination. In the aliquots for $\mathrm{NH}_{3}-\mathrm{N}$ determinations, $1 \mathrm{~mL}$ of 0.18 molar sulfuric acid was added to avoid nitrogen losses. Aliquots were frozen until analysis.

Volatile fatty acid concentrations - acetic $(\mathrm{C} 2)$, propionic (C3), and butyric acids (C4) - were determined by highperformance liquid chromatography, in a chromatograph (Shimadzu model 14-B) equipped with UV detector, precolumn and column (Aminex HPX-87H, BioRad ${ }^{\circledR}$ ). Sulfuric acid was used as eluent at 0.01 molar concentration, at a $0.6 \mathrm{~mL} \mathrm{~min}{ }^{-1}$ flow rate and $50{ }^{\circ} \mathrm{C}$ operating temperature. The detection wavelength was set at $210 \mathrm{~nm}$. Volatile fatty acid concentrations were calculated from the calibration curves using standards $\left(\mathrm{Sigma}^{\circledR}\right.$, analytical grade) at 0.1 to $2.5 \mathrm{~g} \mathrm{~L}^{-1}$ concentrations.

Ammonia nitrogen concentrations were determined by magnesium oxide distillation according to AOAC (1995).

The volume of gas produced during the intervals of $12,24,36,48,72$, and $96 \mathrm{~h}$ of incubation was collected, measured, and stored in $20-\mathrm{mL}$ vacutainer tubes without additive for the gas analysis.

Methane and $\mathrm{CO}_{2}$ gases were analyzed by gas chromatography (Shimadzu ${ }^{\circledR}$ "greenhouse" model) equipped with three packed columns operating at $70^{\circ} \mathrm{C}$. Nitrogen as a carrier gas $\left(25 \mathrm{~mL} \mathrm{~min}^{-1}\right)$, injector $\left(250^{\circ} \mathrm{C}\right)$ with direct sampling of $1 \mathrm{~mL}$, and electron capture detector with $\mathrm{Ni}_{63}$ at $325{ }^{\circ} \mathrm{C}$ were used.

Peak gas areas were determined automatically by integration. Methane volume produced at time $\mathrm{x}$ was calculated in accordance with Tavendale et al. (2005): $\mathrm{CH}_{4}$ production $\left(\mathrm{mL} \mathrm{g}^{-1}\right.$ dry matter $\left.(\mathrm{DM})\right)$ at time $\mathrm{x}=\left(\% \mathrm{CH}_{4}(\mathrm{x})\right.$ $\left.-\% \mathrm{CH}_{4}(\mathrm{x}-1)\right) \times 40 / 100+\mathrm{CH}_{4} \%(\mathrm{x}) \times \mathrm{GP} / 100$, in which $\mathrm{x}$ time $=12,24,36,48,72$, and 96 fermentation $\mathrm{h} ; \mathrm{x}-1=$ previous time; $40=$ head space in the fermentation bottle in $\mathrm{mL}$; GP = volume of gas produced in $\mathrm{mL}$. This calculation resulted in the volume of $\mathrm{CH}_{4}$ gas produced between each time interval. The sum of these volumes resulted in the 
accumulated volume of $\mathrm{CH}_{4}$ for $96 \mathrm{~h}$. The same formula was used to calculate $\mathrm{CO}_{2}$ production.

Digestibility, degradation parameters, effective degradation of organic matter, maximum gas production from the rapidly and slowly degradable fractions and their respective degradation rates, time of colonization, and partition factor data were analyzed using the PROC MIXED of SAS. The following statistical model was used:

$$
Y i j k l=\mu+\alpha i+\beta j+\alpha \beta i j+\gamma k+\text { eijkl, }
$$

in which Yijkl = dependent variables; $\mu=$ overall mean of the observations; $\alpha i=$ fixed effect of the straw $(i=1,2)$; $\beta \mathrm{j}=$ fixed effect of the supplement $(\mathrm{j}=1,2,3,4) ; \alpha \beta \mathrm{ij}=$ straw $\times$ supplement interaction effect $(i=1,2$, and $j=1,2$, $3,4) ; \gamma \mathrm{k}=$ ramdom effect of the period $(\mathrm{k}=1,2,3,4)$; and eijkl $=$ random residual experimental error.

Gas production, $\mathrm{pH}, \mathrm{NH}_{3}, \mathrm{CH}_{4}, \mathrm{CO}_{2}$, and VFA data were analyzed as repeated measures over time using the same procedure. The following statistical model was used: Yijklm, $1=\mu+\alpha \mathrm{i}+\beta \mathrm{j}+\alpha \beta \mathrm{ij}+\varepsilon \mathrm{ij}+\tau \mathrm{k}+\alpha \tau \mathrm{ik}+\beta \tau \mathrm{jk}+\alpha \beta \tau \mathrm{ijk}+$

$$
\gamma l+\text { eijklm, }
$$

in which Yijklm, $1=$ dependent variables; $\mu=$ overall mean of the observations; $\alpha i=$ fixed effect of straw $(i=1,2)$; $\beta \mathrm{j}=$ fixed effect of the supplement $(\mathrm{j}=1,2,3,4) ; \alpha \beta \mathrm{ij}=$ straw $\times$ supplement interaction effect $(i=1,2$, and $j=1,2$, $3,4) ; \varepsilon i \mathrm{j}=$ random residual experimental error; $\tau \mathrm{k}=$ fixed effect of the time $((\mathrm{k}=6,12 \ldots 96)$, or $\mathrm{k}=12,24 \ldots 96))$; $\alpha \tau \mathrm{ik}=$ straw $\times$ time interaction effect; $\beta \tau \mathrm{jk}=$ supplement $\times$ time interaction effect; $\alpha \beta \tau$ ijk $=$ straw $\times$ supplement $\times$ time interaction effect; $\gamma \mathrm{l}=$ ramdom effect of the period $(\mathrm{k}=1$, 2, 3, 4); and eijklm = experimental error associated with the observation Yijklm,1 level.

Using Akaike information criterion, the CS structure (symetry compound) was regarded as the best model for the residual covariance structure.

\section{Results}

There was a significant interaction between the supplement and rice straw nutritional value for in vitro dry matter and organic matter digestibilities (Table 2). The mineral and protein-energy supplement improved the in vitro dry matter and organic matter digestibility of the rice straw with high nutritional value, while the rice straw with low nutritional value without supplementation showed lower values for in vitro dry matter and organic matter digestibility.

Organic matter degradation parameters were influenced only by the rice straw nutritional value (Table 3 ). Straw with high nutritional value had greater content of readily soluble fraction of OM (a) $(\mathrm{P}<0.05)$ compared with the straw with low nutritional value, 188 and $162 \mathrm{~g} \mathrm{~kg}^{-1} \mathrm{OM}$, respectively.

Averages of insoluble fraction, but potentially degradable (b), degradation rate of the insoluble fraction, but potentially degradable (c), and lag time of OM were $651 \mathrm{~g} \mathrm{~kg}^{-1} \mathrm{OM}, 0.0017 \mathrm{~h}^{-1}$, and $9.56 \mathrm{~h}$, respectively (Table 3), without influence of the straw nutritional value.

Table 2 - Interaction effect between the supplement and the rice straw nutritional value on the in vitro dry matter (IVDMD) and in vitro

\begin{tabular}{|c|c|c|c|c|}
\hline \multirow{2}{*}{ Suplement } & \multicolumn{2}{|c|}{ Rice straw nutritional value } & \multirow{2}{*}{ Mean } & \multirow{2}{*}{ SEM } \\
\hline & High & Low & & \\
\hline \multicolumn{5}{|l|}{ IVDMD ( $\mathrm{g} \mathrm{kg}^{-1}$ fresh material) } \\
\hline Without supplement & $473 \mathrm{Ba}$ & $392 \mathrm{Bb}$ & 432 & 0.2190 \\
\hline Mineral and protein-energy supplement (MPES) & $519 \mathrm{Aa}$ & $423 \mathrm{Ab}$ & 472 & 0.2190 \\
\hline Exogenous fibrolytic enzyme supplement (ES) & $467 \mathrm{Ba}$ & $435 \mathrm{Ab}$ & 451 & 0.2190 \\
\hline MPES + ES & $475 \mathrm{Ba}$ & $422 \mathrm{Ab}$ & 448 & 0.2190 \\
\hline Mean & 484 & 417 & & \\
\hline SEM & 0.1548 & 0.1548 & & \\
\hline \multicolumn{5}{|l|}{ Significance $(\mathrm{P}=)$} \\
\hline Nutritional value $\times$ suplement & $<0.0001$ & & & \\
\hline \multicolumn{5}{|l|}{ IVOMD ( $\left.\mathrm{g} \mathrm{kg}^{-1} \mathrm{DM}\right)$} \\
\hline Without supplement & $568 \mathrm{Ba}$ & $495 \mathrm{Bb}$ & 532 & 0.2633 \\
\hline MPES & 604Aa & $515 \mathrm{Ab}$ & 559 & 0.2633 \\
\hline ES & $561 \mathrm{Ba}$ & $529 \mathrm{Ab}$ & 545 & 0.2633 \\
\hline $\mathrm{MPES}+\mathrm{ES}$ & $551 \mathrm{Ba}$ & $519 \mathrm{Ab}$ & 535 & 0.2633 \\
\hline Mean & 571 & 515 & & \\
\hline SEM & 0.1862 & 0.1862 & & \\
\hline \multicolumn{5}{|l|}{ Significance $(\mathrm{P}=)$} \\
\hline Nutritional value $\times$ suplement & $<0.0001$ & & & \\
\hline
\end{tabular}
organic matter (IVOMD) digestibility

DM - dry matter; SEM - standard error of the mean.

Different uppercase letters in the column and different lowercase letters in the row differ statistically $(\mathrm{P}<0.05)$ by Tukey test. 
Effective degradability obtained for the solid fraction passage rates $\left(\mathrm{k}=0.02\right.$ and $\left.0.05 \mathrm{~h}^{-1}\right)$ were influenced by the straw nutritional value $(\mathrm{P}<0.05)$ (Table 3$)$.

There was an interaction effect between the straw nutritional value and the incubation time on the in vitro cumulative gas production (Table 4). From $18 \mathrm{~h}$ of incubation, the cumulative gas production of highnutritional value straw was greater than for the low-nutritional value straw and at the end of the $96 \mathrm{~h}$ of incubation, this production was 200.22 and $186.13 \mathrm{~mL} \mathrm{~g}^{-1} \mathrm{OM}$, respectively, showing better fermentation for the high-nutritional value straw.
Maximum gas production of the rapidly degradable fraction of organic matter (A) was influenced by the straw nutritional value. High-nutritional value straw produced $113.98 \mathrm{~mL}$, while the low value produced $75.61 \mathrm{~mL}$ of gases related to fraction A. However, the maximum gas production of the slowly degradable fraction of organic matter (D) was influenced by straw nutritional value and by the supplement. Low- and high-nutritional value straws produced 113.43 and $89.27 \mathrm{~mL}$, respectively $(\mathrm{P}<0.05)$. Supplements contributed to the reduction in the maximum gas production related to fraction D compared with the treatment without supplement (Table 5).

Table 3 - Effect of the rice straw nutritional value and the supplement on the organic matter degradation parameters (a, b, c, and lag time) and organic matter effective degradability $\left(\mathrm{g} \mathrm{kg}^{-1} \mathrm{OM}\right)$ mesuared at outflow rate $\mathrm{k}=0.02$ and $0.05 \mathrm{~h}^{-1}$

\begin{tabular}{|c|c|c|c|c|c|c|}
\hline Parameter & $\mathrm{a}\left(\mathrm{g} \mathrm{kg}^{-1} \mathrm{OM}\right)$ & $\mathrm{b}\left(\mathrm{g} \mathrm{kg}^{-1} \mathrm{OM}\right)$ & $\mathrm{c}(\mathrm{h})$ & lag time $(\mathrm{h})$ & ED 0.02 & ED 0.05 \\
\hline \multicolumn{7}{|l|}{ Straw nutritional value } \\
\hline High & $188 \mathrm{~A}$ & 656 & 0.017 & 9.41 & $442 \mathrm{~A}$ & 297A \\
\hline Low & 168B & 645 & 0.017 & 9.71 & 408B & 266B \\
\hline SEM & 0.53 & 2.32 & 0.0012 & 0.68 & 0.74 & 0.65 \\
\hline \multicolumn{7}{|l|}{ Suplement } \\
\hline Without supplement & 183 & 661 & 0.016 & 10.25 & 424 & 277 \\
\hline Mineral and protein-energy supplement (MPES) & 193 & 675 & 0.016 & 9.83 & 425 & 283 \\
\hline Exogenous fibrolytic enzyme supplement (ES) & 187 & 652 & 0.017 & 9.30 & 420 & 276 \\
\hline $\mathrm{MPES}+\mathrm{ES}$ & 192 & 617 & 0.019 & 8.86 & 432 & 289 \\
\hline SEM & 0.74 & 3.28 & 0.0017 & 0.96 & 1.05 & 0.92 \\
\hline \multicolumn{7}{|l|}{ Significance $(\mathrm{P}=)$} \\
\hline Nutrition value & $<0.0001$ & 0.5401 & 0.7170 & 0.4988 & $<0.0001$ & $<0.0001$ \\
\hline Suplement & 0.1572 & 0.1300 & 0.1445 & 0.1536 & 0.4108 & 0.1849 \\
\hline Nutritional value $\times$ suplement & 0.3115 & 0.6349 & 0.2517 & 0.5617 & 0.4301 & 0.3154 \\
\hline
\end{tabular}

OM - organic matter; ED - effective degradability; SEM - standard error of the mean.

Different uppercase letters in the column differ statistically $(\mathrm{P}<0.05)$ by Tukey test.

Table 4 - Effect of interaction between the rice straw nutritional value and the incubation time on the in vitro cumulative gas production $\left(\mathrm{mL} \mathrm{g}^{-1} \mathrm{OM}\right)$

\begin{tabular}{|c|c|c|c|c|}
\hline \multirow{2}{*}{ Incubation time (hours) } & \multicolumn{2}{|c|}{ Rice straw nutritional value } & \multirow{2}{*}{ Mean } & \multirow{2}{*}{ SEM } \\
\hline & High & Low & & \\
\hline 1 & $0.03 \mathrm{~K}$ & 0I & 0.01 & 1.30 \\
\hline 3 & $0.92 \mathrm{~K}$ & $0.84 \mathrm{I}$ & 0.87 & 1.30 \\
\hline 6 & $5.45 \mathrm{JK}$ & $2.12 \mathrm{I}$ & 3.78 & 1.30 \\
\hline 9 & $10.57 \mathrm{IJ}$ & $4.58 \mathrm{I}$ & 7.66 & 1.30 \\
\hline 12 & $15.62 \mathrm{I}$ & $7.12 \mathrm{I}$ & 11.37 & 1.30 \\
\hline 18 & $30.82 \mathrm{Ha}$ & $18.63 \mathrm{Hb}$ & 24.72 & 1.30 \\
\hline 24 & $50.82 \mathrm{Ga}$ & $36.26 \mathrm{~Gb}$ & 43.54 & 1.30 \\
\hline 30 & $78.74 \mathrm{Fa}$ & $60.36 \mathrm{Fb}$ & 69.55 & 1.30 \\
\hline 36 & $103.69 \mathrm{Ea}$ & $83.38 \mathrm{~Eb}$ & 93.53 & 1.30 \\
\hline 48 & $134.97 \mathrm{Da}$ & $114.84 \mathrm{Db}$ & 124.90 & 1.30 \\
\hline 60 & $161.71 \mathrm{Ca}$ & $144.86 \mathrm{Cb}$ & 153.28 & 1.30 \\
\hline 72 & $179.93 \mathrm{Ba}$ & $165.40 \mathrm{Bb}$ & 172.66 & 1.30 \\
\hline 96 & $200.22 \mathrm{Aa}$ & $186.13 \mathrm{Ab}$ & 193.18 & 1.30 \\
\hline Mean & 69.54 & 58.89 & & \\
\hline SEM & 0.49 & 0.49 & & \\
\hline \multicolumn{5}{|l|}{ Significance $(\mathrm{P}=)$} \\
\hline Nutritional value $\times$ incubation time & $<0.0001$ & & & \\
\hline
\end{tabular}

OM - organic matter; SEM - standard error of the mean.

Different uppercase letters in the column and different lowercase letters in the row differ statistically $(\mathrm{P}<0.05)$ by Tukey test. 
The degradation rate of slowly degradable fraction (E) was greater for the low-nutritional value straw than the high nutritional value, 0.026 and $0.022 \mathrm{~h}^{-1}$, respectively $(\mathrm{P}<0.05)$. The lag times of rapidly $(\mathrm{C}, \mathrm{h})$ and slowly degradable $(\mathrm{F}, \mathrm{h})$ fractions were greater for the highnutritional value straw than for the lower value $(\mathrm{P}>0.05)$.
The partition factor, was not affected by treatments $(\mathrm{P}>0.05)$, indicating that the fermentation efficiency was not affected by supplementation (Table 5).

The $\mathrm{pH}$ decreased, while the $\mathrm{NH}_{3}-\mathrm{N}$ concentration increased with the increase in incubation time (Table 6). The $\mathrm{NH}_{3}-\mathrm{N}$ concentrations were also influenced by the straw

Table 5 - Effect of the rice straw nutritional value and the supplement on the maximum gas production of organic matter of the rapidly $(\mathrm{A}, \mathrm{mL})$ and slowly $(\mathrm{D}, \mathrm{mL})$ degradable fractions and their respective degradation rates $(\mathrm{B}$ and $\mathrm{E}, \mathrm{h})$, lag time $(\mathrm{C}$ and $\mathrm{F}, \mathrm{h})$, and partition factor ( $\mathrm{mg} \mathrm{OM} / \mathrm{mL}$ gases, $36 \mathrm{~h}$ of incubation)

\begin{tabular}{|c|c|c|c|c|c|c|c|}
\hline Parameter & $\mathrm{A}(\mathrm{mL})$ & $\mathrm{B}(\mathrm{h})$ & $\mathrm{C}(\mathrm{h})$ & $\mathrm{D}(\mathrm{mL})$ & $\mathrm{E}(\mathrm{h})$ & $\mathrm{F}(\mathrm{h})$ & $\mathrm{PF}\left(\mathrm{mg} \mathrm{mL}^{-1}\right)$ \\
\hline \multicolumn{8}{|l|}{ Straw nutritional value } \\
\hline High & $113.98 \mathrm{~A}$ & 0.044 & $19.74 \mathrm{~A}$ & $89.27 \mathrm{~B}$ & $0.022 \mathrm{~B}$ & $36.34 \mathrm{~A}$ & 2.68 \\
\hline Low & $75.61 \mathrm{~B}$ & 0.038 & $13.04 \mathrm{~B}$ & $113.43 \mathrm{~A}$ & $0.026 \mathrm{~A}$ & $30.60 \mathrm{~B}$ & 2.61 \\
\hline \multicolumn{8}{|l|}{ Suplement } \\
\hline Without supplement & 94.05 & 0.043 & 14.92 & $110.90 \mathrm{~A}$ & 0.022 & 34.91 & 2.37 \\
\hline Mineral and protein-energy supplement (MPES) & 100.01 & 0.041 & 14.66 & $88.08 \mathrm{~B}$ & 0.022 & 32.17 & 2.88 \\
\hline SEM & 7.19 & 0.47 & 2.73 & 7.86 & 0.22 & 3.00 & 0.17 \\
\hline \multicolumn{8}{|l|}{ Significance $(\mathrm{P}=)$} \\
\hline Nutrition value & $<0.0001$ & 0.0987 & 0.0004 & 0.0003 & 0.0242 & 0.0134 & 0.6844 \\
\hline Suplement & 0.6895 & 0.9635 & 0.2803 & 0.0408 & 0.6238 & 0.8402 & 0.2867 \\
\hline Nutritional value $\times$ suplement & 0.4071 & 0.8900 & 0.5968 & 0.6769 & 0.2910 & 0.9407 & 0.2298 \\
\hline
\end{tabular}

$\mathrm{PF}$ - partition factor; OM - organic matter; SEM - standard error of the mean.

Different uppercase letters in the column differ statistically $(\mathrm{P}<0.05)$ by Tukey test.

Table 6 - Effect of the rice straw nutritional value, the supplement, and the incubation time on the $\mathrm{pH}$, amonical nitrogen $\left(\mathrm{NH}_{3}-\mathrm{N}\right)$, and carbon dioxide $\left(\mathrm{CO}_{2}\right)$ values

\begin{tabular}{|c|c|c|c|c|}
\hline Parameter & $\mathrm{pH}$ & $\mathrm{NH}_{3}-\mathrm{N}\left(\mathrm{mg} \mathrm{dL}^{-1}\right)$ & Incubation time (h) & $\mathrm{CO}_{2}\left(\mathrm{~mL} \mathrm{~g}^{-1} \mathrm{DM}\right)$ \\
\hline \multicolumn{5}{|l|}{ Straw nutritional value } \\
\hline High & 7.10 & $14.05 \mathrm{~B}$ & & $19.03 \mathrm{~A}$ \\
\hline SEM & 0.028 & 0.11 & & 0.1896 \\
\hline \multicolumn{5}{|l|}{ Suplement } \\
\hline Without supplement & 7.00 & $13.35 \mathrm{~B}$ & & $18.74 \mathrm{~A}$ \\
\hline MPES + ES & 7.12 & $14.93 \mathrm{~A}$ & & $17.57 \mathrm{~B}$ \\
\hline SEM & 0.040 & 0.15 & & 0.2670 \\
\hline \multicolumn{5}{|l|}{ Incubation time $(\mathrm{h})$} \\
\hline 6 & $7.19 \mathrm{~A}$ & $11.87 \mathrm{E}$ & 12 & $19.63 \mathrm{~A}$ \\
\hline 12 & 7.09AB & $12.54 \mathrm{DE}$ & 24 & $19.80 \mathrm{~A}$ \\
\hline \multicolumn{5}{|l|}{ Significance $(\mathrm{P}=)$} \\
\hline Nutritional value & 0.6949 & 0.0399 & & $<0.0001$ \\
\hline Suplement & 0.1095 & $<0.0001$ & & 0.0020 \\
\hline Incubation time & 0.0042 & $<0.0001$ & & $<0.0001$ \\
\hline Nutritional value $\times$ suplement & 0.8219 & 0.9383 & & 0.4105 \\
\hline Nitritional value $\times$ incubation time & 0.3318 & 0.1139 & & 0.5586 \\
\hline Suplement $\times$ incubation time & 0.7613 & 0.5552 & & 1.000 \\
\hline Nutritional value $\times$ supplement $\times$ incubation time & 0.4054 & 0.8061 & & 1.000 \\
\hline
\end{tabular}

DM - dry matter; SEM - standard error of the mean.

Different uppercase letters in the column differ statistically $(\mathrm{P}<0.05)$ by Tukey test. 
nutritional value $(\mathrm{P}<0.05)$ and the supplement $(\mathrm{P}<0.05)$. Low- and high-nutritional value straw showed $\mathrm{NH}_{3}-\mathrm{N}$ concentrations of 14.05 and $14.38 \mathrm{mg} \mathrm{dL}^{-1}$, respectively. The MPES + ES and MPES supplements showed the highest concentrations of $\mathrm{NH}_{3}-\mathrm{N}, 14.93$ and $14.79 \mathrm{mg} \mathrm{dL}^{-1}$, respectively, differing from the supplements ES and WS, whose $\mathrm{NH}_{3}-\mathrm{N}$ concentrations were 13.78 and $13.35 \mathrm{mg} \mathrm{dL}^{-1}$, respectively (Table 6).

The volume of $\mathrm{CO}_{2}$ produced $\left(\mathrm{mL} \mathrm{g}^{-1} \mathrm{DM}\right)$ was related to the straw nutritional value, the supplement, and the incubation time (Table 6). Low-nutritional value straw produced $16.85 \mathrm{~mL} \mathrm{~g}^{-1} \mathrm{DM}$, while the high value produced $19.03 \mathrm{~mL} \mathrm{~g}^{-1} \mathrm{DM}$ of $\mathrm{CO}_{2}$. The supplements MPES and MPES + ES produced lower volumes of $\mathrm{CO}_{2}$ (17.40 and $\left.17.57 \mathrm{~mL} \mathrm{~g}^{-1} \mathrm{DM}\right)$ compared with supplements WS and ES (18.74; $\left.18.07 \mathrm{~mL} \mathrm{~g}^{-1} \mathrm{DM}\right)$, being important for mitigating $\mathrm{CO}_{2}$. As the incubation time increased from 12 to $96 \mathrm{~h}$, the $\mathrm{CO}_{2}$ production decreased from 19.63 to $15.88 \mathrm{~mL} \mathrm{~g}^{-1} \mathrm{DM}$, respectively.

There was an interaction between the straw nutritional value and the incubation time on in vitro $\mathrm{CH}_{4}$ production (Table 7). In the first $12 \mathrm{~h}$ of fermentation, $\mathrm{CH}_{4}$ production was similar between straws. Starting from $12 \mathrm{~h}$ to the end of the incubation period, there was a linear increase in the $\mathrm{CH}_{4}$ volumes for both straws; however, greater $\mathrm{CH}_{4}$ volume was produced by high-nutritional value straw compared with the low-nutritional value straw. Nevertheless, at the end of the 96-h incubation, the $\mathrm{CH}_{4}$ production rate in the total gas volume was 0.15 for both straws.

Volatile fatty acid concentration and the acetate: propionate ratio were influenced by the interaction between the straw nutritional value and the incubation time (Table 8). The greater acetic acid concentration and the lowest propionic acid concentration were observed for the lownutritional value straw with $6 \mathrm{~h}$ of incubation (71.80 and

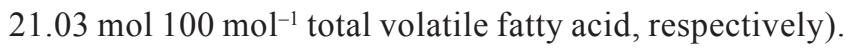
Thus, the greater acetate:propionate ratio was also observed for this straw (3.60 mol $100 \mathrm{~mol}^{-1}$ total volatile fatty acid) (Table 8). However, the greater concentration of butyric acid was observed for the high-nutritional value straw with $6 \mathrm{~h}$ of incubation (7.61 mol $100 \mathrm{~mol}^{-1}$ total volatile fatty acid).

\section{Discussion}

In this study, the highest IVDMD and IVOMD were observed for the straw with less lignification and silicified cell wall (high nutritional value) when supplemented with mineral and protein-energy supplement. For the same straw, mineral and protein-energy supplement inhibited the effect of the exogenous fibrolitic enzyme, since the combination of these supplements resulted in a lower in vitro digestibility in relation to other supplements. These results suggest that the improvement of IVDMD and IVOMD depends on the forage chemical characteristics and the supplement used, corroborating with Morgavi et al. (2000), who stated that more detailed knowledge of the interaction between the supplement with the forage, the host, and the rumen microorganisms is necessary for the correct application of this technology. Previous research had also identified variation in rice straw digestibility (Vadiveloo, 1992; Vadiveloo, 1995) and improvement of forage in vitro digestibility with the use of mineral and protein-energy supplement (Barbosa et al., 2007) and exogenous fibrolytic enzyme (Beauchemin et al., 2003; Bassiouni et al., 2011).

With the use of supplements, an improvement in the parameters of in vitro organic matter ruminal degradability

Table 7 - Effect of the interaction between the rice straw nutritional value and the incubation time on the in vitro cumulative methane production $\left(\mathrm{mL} \mathrm{g}^{-1} \mathrm{DM}\right)$

\begin{tabular}{|c|c|c|c|c|}
\hline \multirow{2}{*}{ Incubation time (hours) } & \multicolumn{2}{|c|}{ Rice straw nutritional value } & \multirow{2}{*}{ Mean } & \multirow{2}{*}{ SEM } \\
\hline & High & Low & & \\
\hline 12 & $1.16 \mathrm{E}$ & $0.75 \mathrm{~F}$ & 0.96 & 0.53 \\
\hline 24 & 7.97Da & $5.64 \mathrm{~Eb}$ & 6.80 & 0.53 \\
\hline 36 & $14.97 \mathrm{Ca}$ & $11.66 \mathrm{Db}$ & 13.32 & 0.53 \\
\hline 48 & $22.32 \mathrm{Ba}$ & $18.46 \mathrm{Cb}$ & 20.39 & 0.53 \\
\hline 72 & $27.43 \mathrm{Aa}$ & $23.18 \mathrm{Bb}$ & 25.30 & 0.53 \\
\hline 96 & $29.39 \mathrm{Aa}$ & $27.03 \mathrm{Ab}$ & 28.31 & 0.53 \\
\hline Mean & 17.21 & 14.45 & & \\
\hline SEM & 0.45 & 0.45 & & \\
\hline \multicolumn{5}{|l|}{ Significance $(\mathrm{P}=)$} \\
\hline Nutritional value $\times$ incubation time & 0.0017 & & & \\
\hline
\end{tabular}


of rice straw was expected. However, the supplements did not help carbohydrate release and did not provide enough nitrogen to improve these parameters, probably due to the limiting nitrogen content in the incubated straws.

Gas production is an indirect measure of substrate degradation, mainly of carbohydrates (Menke, 1979). In the current research, there was interaction between the incubation time and the nutritional value of rice straw on the in vitro cumulative gas production. At 9 and $12 \mathrm{~h}$ of incubation, there was an increase in gas production due to accumulation of indirect gas products of reaction between the buffer and the propionic acid generated from the fermentation of rapidly degradable carbohydrates and the indirect gas that starts to be produced from the structural carbohydrate degradation. According to Chai et al. (2004), the gases produced in the first $3 \mathrm{~h}$ of incubation correspond to the soluble components of the fermentation. To the extent that the incubation time increased, the volume of gas produced was increased by the effect of the structural carbohydrate fermentation of the substrate (Theodorou

Table 8 - Effect of interaction between the rice straw nutritional value and the incubation time on the volatile fatty acid concentration (mol $100 \mathrm{~mol}^{-1}$ total volatile fatty acid)

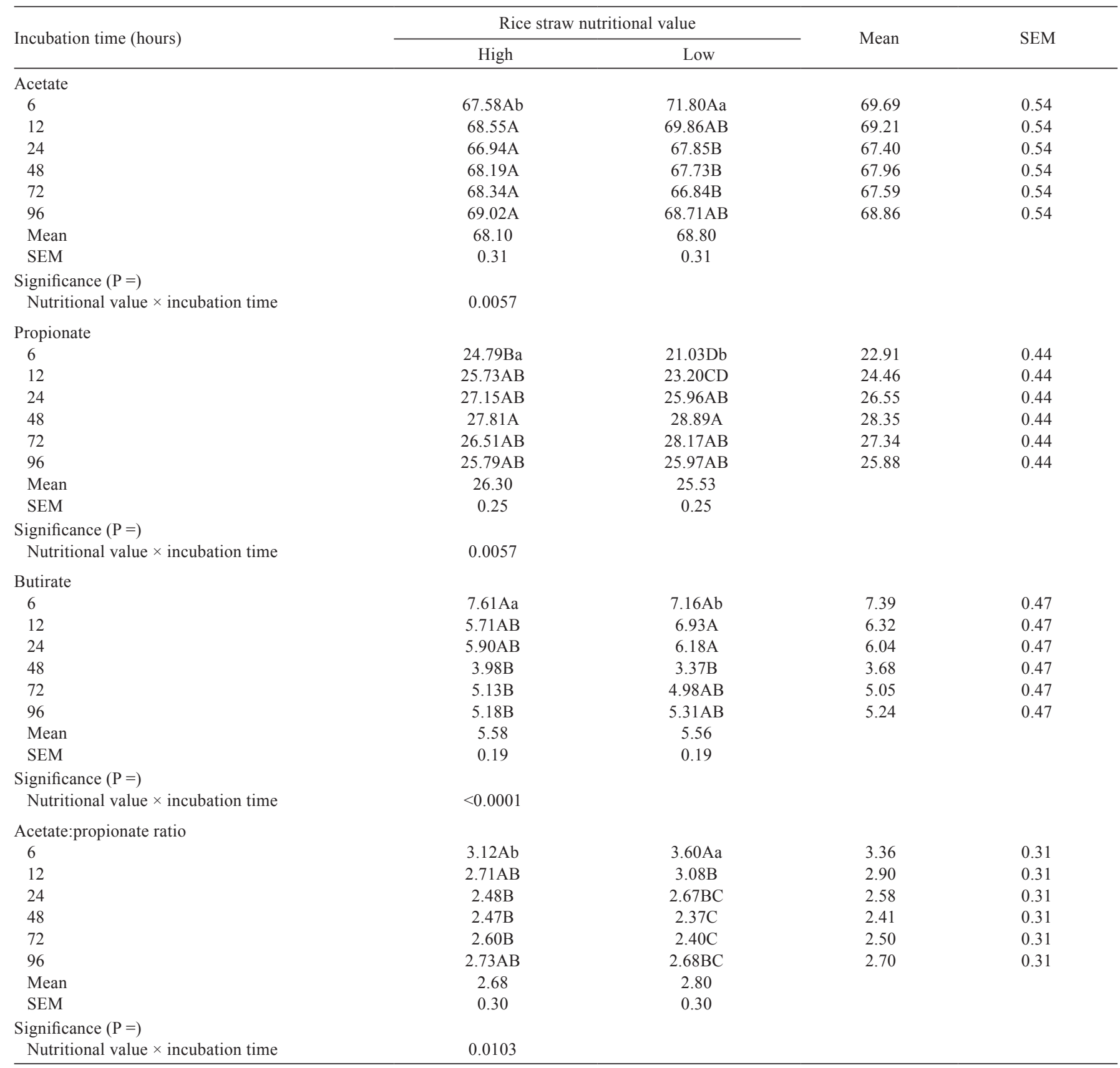

SEM - standard error of the mean.

Different uppercase letters in the column and different lowercase letters in the row differ statistically $(\mathrm{P}<0.05)$ by Tukey test. 
et al., 1994) and at the end of $96 \mathrm{~h}$ of incubation, greater cumulative gas production was observed for high-nutritional value straw due to greater organic matter degradadability in this straw, corroborating with Menke et al. (1979). However, the fermentation pattern was similar between straws and gas production curves corresponded to the fermentation pattern to a substrate with forage predominance, in which, initially, sugars are fermented and later, the structural components (Getachew et al., 2005).

Supplementation with MPES and MPES + ES did not affect the in vitro cumulative gas production. Liu and Ørskov (2000) reported that treatment of rice straw with several levels of cellulase did not affect the cumulative gas production over $24 \mathrm{~h}$ of incubation. However, Eun et al. (2006) treated Akibali rice straw with six different enzyme products $\left(1.25 \mathrm{mg} \mathrm{g}^{-1} \mathrm{DM}\right)$ and found that only two (product composed of cellulase and hemicellulase and product containing protease) increased cumulative gas production over $24 \mathrm{~h}$ of incubation compared with untreated rice straw. Therefore, the inconsistencies in the responses with enzyme supplements were probably related to supplement characteristics, including the enzyme activities in the conditions of rumen (temperature and $\mathrm{pH}$ ), as well as the substrate composition (Yang et al., 2011).

The partition factor is an indicator of fermentation efficiency; thus, high value of partition factor indicates a greater incorporation of degraded organic matter in microbial mass, thereby increasing the microbial synthesis efficiency. The greater the partition factor value, the greater the forage dry matter intake (Makkar, 2004) and lower the $\mathrm{CH}_{4}$ production in ruminants (Blümmel et al., 1999). According to Makkar (2004), partition factor may vary from 2.74 to $4.41 \mathrm{mg}$ of degraded $\mathrm{OM} \mathrm{mL}^{-1}$ of gases produced. In the current research, the partition factor values ranged from 2.37 to 2.88 and were not influenced by the straw nutritional value or the supplement.

The $\mathrm{pH}$ is an important variable to indicate the rumen status (Gunun et al., 2013), since it regulates the affinity of microorganisms with the substrate. Thus, values near neutral $\mathrm{pH}$ improve the bacteria adhesion to the fiber (Allen and Mertens, 1988). In the current study, the $\mathrm{pH}$ ranged from 6.94 to 7.19. These values are considered optimal for the normal rumen fermentation, for the synthesis of volatile fatty acid, and microbial protein (Wanapat and Pimpa, 1999; Anantasook et al., 2012), and are also within the range of 6.2 to 7.2, considered appropriate for optimal microbial activity (Van Soest, 1994), as expected for diets based on forage.

In vitro $\mathrm{NH}_{3}-\mathrm{N}$ concentration works as an indicator of protein degradability because there is no nitrogen absorption or recycling, as in the in vivo rumen environment (Detmann et al., 2011). The average $\mathrm{NH}_{3}-\mathrm{N}$ concentration of all treatments was $14.21 \mathrm{~mL} \mathrm{dL}^{-1}$ and was within the optimum ruminal $\mathrm{NH}_{3}-\mathrm{N}$ range of 12 and $17 \mathrm{~mL} \mathrm{dL}^{-1}$ for optimal fermentation and rumen microbial growth (Anantasook and Wanapat, 2012; Lunsin et al., 2012). As expected, MPES and MPES + ES supplements increased the dietary levels of carbohydrate and nitrogen, resulting in an increase in $\mathrm{NH}_{3}-\mathrm{N}$ concentration levels and decrease in $\mathrm{CO}_{2}$ production due to the microbial mass formation.

Within the first $12 \mathrm{~h}$ after incubation, there was lower $\mathrm{CH}_{4}$ production for both straws evaluated, as this period includes the lag-time phase, in which there is no methanogenesis until the sites available for microbial attachment are saturated and these synthesize its structures and enzymes (Franco et al., 2013). The linear increase in $\mathrm{CH}_{4}$ volume for high and low straw nutritional value, from $12 \mathrm{~h}$ until the end of the incubation period, was associated with the slowly digestible fraction fermentation and, consequently, with acetic and butyric acid production (Getachew et al., 2005; Lee et al., 2011). The production of $\mathrm{CH}_{4}$ at $96 \mathrm{~h}$ of incubation was greater for high-nutritional value straw compared with low value straw, possibly due to better digestibility of the former, corroborating with Kurihara et al. (1995), who observed that $\mathrm{CH}_{4}$ production in cows fed forage with low digestibility was lower than in cows fed high forage digestibility. However, this disagrees with other studies that observed that $\mathrm{CH}_{4}$ production tends to decrease with increasing protein concentration and tends to increase with increasing fiber content of the feed (Johnson and Johnson, 1995; Getachew et al., 2005). Another possibility may be related to the fiber degradability, since forage with greater content of effectively degraded fiber promotes greater $\mathrm{CH}_{4}$ production (Demarchi et al., 2003).

Due to the lack of supplement effect on the degradation parameters, cumulative gas production, gas production kinetics, and $\mathrm{CH}_{4}$ production, volatile fatty acid concentrations were measured to further explore any potential effect of the supplements on the rumen fermentation. However, the supplements did not affect the volatile fatty acid concentrations, but these concentrations were influenced by the interaction between the straw nutritional value and the incubation time. High levels of volatile fatty acids observed at the beginning of the fermentation can be explained by rumen fluid being obtained from animals fed a diet based on alfalfa hay. The dominance of the acetic acid concentration observed in the current study shows that when the diet had high forage content, ruminal fermentation occurred preferentially in 
this way and was associated with high $\mathrm{CH}_{4}$ production, corroborating with Nussio et al. (2011).

Acetic:propionic acid ratio is an important point in rumen methanogenesis, since greater energy losses in the $\mathrm{CH}_{4}$ form is related to the greater acetic:propionic acid ratio (Johnson and Johnson, 1995). Also, as the propionic acid is the most important fatty acid precursor of the glucose synthesis (Nagajara et al., 1997), a low acetic:propionic acid ratio reflects an improvement of the food nutritional value. In the current research, there was no influence of the supplement on the acetic:propionic acid ratio and on improvement of the straw nutritional value. The results did not differ from results of Eun et al. (2006), who observed reduction in theacetic:propionic acid ratio with $\mathrm{EX}$ and PROT enzymatic treatment of rice straw, suggesting that microbial interactions lead to decreased acetate and increased propionate formation from the products of cellulose and hemicellulose hydrolyses when certain types of exogenous enzymes were added to rice straw.

\section{Conclusions}

The use of mineral and protein-energy supplement and mineral and protein-energy + exogenous fibrolytic enzymes supplements can be used as strategy to mitigate carbon dioxide in ruminant production systems that use rice straws.

\section{Acknowledgments}

The authors thank the Conselho Nacional de Desenvolvimento Científico e Tecnológico (CNPq), Fundação de Amparo à Pesquisa do Estado do Rio Grande do Sul (FAPERGS), Alltech Incorporation, and Azevedo Bento S/A for the financial support.

\section{References}

Allen, M. S. and Mertens, D. R. 1988. Evaluating constraints on fiber digestion by rumen microbes. Symposium: rumen productivity. The Journal of Nutrition 118:261-270.

Anantasook, N. and Wanapat, M. 2012. Influence of rain tree pod meal supplementation on rice straw based diets using in vitro gas fermentation technique. Asian-Australasian Journal of Animal Science 25:325-334

AOAC - Association of Official Analytical Chemistry. 1975. Official methods of analysis. 12th ed. AOAC International, Washington, DC.

AOAC - Association of Official Analytical Chemists. 1995. Official methods of analysis. 16th ed. AOAC, Washington, DC.

Bassiouni, M. I.; Gaafar, H. M. A.; Saleh, M. S.; Mohi El-Din, A. M. A. and Elshora, M. A. H. 2011. Evaluation of rations supplemented with fibrolytic enzyme on dairy cows performance. In situ ruminal degradability of different feedstuffs. Livestok Research for Rural Development. Available at: <http://www.lrrd.org/lrrd23/4/ bass23081.htm> Accessed on: Nov. 24, 2015.

Barbosa, F. A.; Graça, D. S.; Maffei, W. E.; Silva Júnior, F. V. and Souza, G. M. 2007. Desempenho e consumo de matéria seca de bovinos sob suplementação protéico-energética, durante a época de transição água-seca. Arquivo Brasileiro de Medicina Veteterinária e Zootecnia 59:160-167.

Beauchemin, K. A.; Colombatto, D.; Morgavi, D. P. and Yang, W. Z. 2003. Use of exogenous fibrolytic enzymes to improve feed utilization by ruminants. Journal of Animal Science 81:37-47.

Blümmel, M.; Mgomezulu, R.; Chen, X. B.; Makkar, H. P. S.; Becker, K. and Ørskov, E. R. 1999. The modification of an in vitro gas production test to detect roughage related differences in in vivo microbial protein synthesis as estimated by the excretion of purine derivates. Journal of Agricultural Science 133:335-340.

Chai, W. Z.; Gelder, A. H. and Cone, J. W. 2004. Relationship between gas production and starch degradation in feed samples. Animal Feed Science and Technology 114:195-204.

Demarchi, J. J. A. A.; Manella, M. Q. A.; Lourenço, J.; Alleoni, G. F.; Frigueto, R. S.; Primavesi, O. and Lima, M. A. 2003. Daily methane emission at different seasons of the year by Nelore cattle in Brazil grazing Brachiaria brizantha cv. Marandu: preliminary results. p.19. In: Proceedings of the 9th World Conference on Animal Production. SBZ, WAAP, ALPA, UFRGS, Porto Alegre.

Detmann, E.; Queiroz, A. C.; Zorzi, K. H.; Mantovani, C.; Bayão, G. F. V. and Gomes M. P. C. 2011. Degradação in vitro da fibra em detergente neutro de forragem tropical de baixa qualidade em função da suplementação com proteína verdadeira e/ou nitrogênio não-protéico. Revista Brasileira de Zootecnia 40:1272-1279.

Doyle, P. T.; Devendra, C. and Pearce, G. R. 1986. Rice straw as a feed for ruminants. 1 th ed. International Development Program of Australian Universites and Coleges Limited, Canberra, AU.

Eun, J.-S.; Beauchemin, K. A.; Hong, S.-H. and Bauer, M. W. 2006. Exogenous enzymes added to untreated or ammoniated rice straw: Effects on in vitro fermentation characteristics and degradability. Animal Feed Science and Technology 131:86-101.

FAO - Food and Agriculture Organization of the United Nations. 2016. Rice market monitor. Available at: <http://www.fao.org/ economic/est/publications/rice-publications/rice-market-monitor$\mathrm{rmm} / \mathrm{en} /$ / . Accessed on: Oct. 29, 2016.

Fike, G. D.; Simmis, D. D.; Cochran, R. C.; Vanzant, E. S.; Kutil, G. L. and Brandt Jr, R. T. 1995. Protein supplementation of ammoniated wheat straw: effect on performance and forage utilization of beef cattle. Journal of Animal Science 73:1595-1601.

Franco, A. L. C.; Mizubuti, I. Y.; Azevêdo, J. A. G.; Ribeiro, E. L. A.; Pereira, E. S. Peixoto, E. L. T.; Ferreira, D. M. F. and Andrade Neto, A. Q. 2013. Fermentação ruminal e produção de metano in vitro de dietas contendo torta de algodão. Semina: Ciências Agrárias 34:1955-1966.

Getachew, G.; DePeters, E. J.; Robinson, P. H. and Fadel, J. G. 2005. Use of an in vitro rumen gas production technique to evaluate microbial fermentation of ruminant feeds and its impact on fermentation products. Animal Feed Science and Technology 123124:547-559.

Goering, H. K. and Van Soest, P. J. 1970. Forage fiber analysis (apparatus, reagents, procedures, and some applications). Agriculture Handbook No. 379. ARS-USDA, Washington, D.C., USA.

Gunun, P.; Wanapat, M. and Anantasook, N. 2013. Effects of physical form and urea treatment of rice straw on runen fermentation, microbial protein synthesis and nutrient digestibility in dairy steers. Asian-Australasian Journal of Animal Science 26:1689-1697.

Johnson, K. A. and Johnson, D. E. 1995. Methane emissions from cattle. Journal of Animal Science 73:2483-2492. 
Kurihara, M.; Kume, S.; Aii, T.; Takahashi, S.; Shibata, M. and Nishida, T. 1995. Feeding method for dairy cattle to cope with global warming. Technical assessment based on energy metabolism. p.21-107. In: The 29th bulletin of the Kyushu National Agricultural Experiment Station. Japan.

Lee, S. Y.; Lee, S. M.; Choa, Y. B.; Kam, D. K.; Lee, S. C.; Kim, C. H. and Seo, S. 2011. Glycerol as a feed supplement for ruminants: In vitro fermentation characteristics and methane production. Animal Feed Science and Technololgy 166-167:269-274.

Leng, R. A. 1990. Factors affecting the utilization of "poor quality" forages by ruminants particularly under tropical conditions. Nutrition Research Reviews 3:277-303.

Lima, J. O. A. A. 2002. Mistura múltipla para bovinos em pastejo na região dos tabuleiros costeiros. EMBRAPA dos Tabuleiros Costeiros, Aracajú.

Liu, J. X. and Ørskov, E. R. 2000. Cellulase treatment of untreated and steam pre treated rice straw-effect on in vitro fermentation characteristics. Animal Feed Science and Technology 88:189-200.

Lunsin, R.; Wanapat, M. and Rowlinson, P. 2012. Effect of cassava hay and rice bran oil supplementation on rumen fermentation, milk yield and milk composition in lactating dairy cows. AsianAustralasian Journal of Animal Science 25:1364-1373.

Makkar, H. P. S. 2004. Recent advances in the in vitro gas method for evaluation of nutritional quality of feed resources. p.55-88. In: Assessing quality and safety of the animal feeds. FAO Animal Production and Health Series Paper 160. FAO, Roma.

Mauricio, R. M.; Mould, F. L.; Dhanoa, M. S.; Owen, E.; Channa, K. S. and Theodorou, M. K. 1999. A semi-automated in vitro gas production technique for ruminant feedstuff evaluation. Animal Feed Science and Technology 79:321-330.

McDonald, I. 1981. A revised model for the estimation of protein degradability in the rumen. Journal of Agricultural Science 96:251-252.

Menke, K. H.; Raab, L.; Salewski, A.; Steingass, H.; Fritz, D. and Schneider, W. 1979. The estimation of the digestibility and metabolizable energy content of ruminant feedingstuffs from the gas production when they are incubated with rumen liquor in vitro. Journal of Agricultural Science 93:217-222.

Morgavi, D. P.; Beauchemin, K. A.; Nsereko, V. L.; Rode, L. M.; Iwaasa, A. D.; Yang, W. Z.; McAllister, T. A. and Wang, Y. 2000. Synergy between ruminal fibrolytic enzymes and enzymes from Trichoderma longibrachiatum. Journal of Dairy Science 83:1310-1321.

Nagajara, T. G.; Newbold, C. J.; Van Nevel, C. J. and Demeyer, D. I. 1997. Manipulation of ruminal fermentation. p.523-632. In: The rumen microbial ecosystem. Hobson, P. N., ed. New York, Blackie.

Newbold, J. 1997. Proposed mechanisms for enzymes as modifiers of ruminal fermentation. p.3-7. In: Proceedings of the 16th Florida Ruminant Nutrition Symposium. Gainesville.

NRC - National Research Council. 1996. Nutrient requirements of beef cattle. 7th ed. National Academy Press, Washington, DC.
Nsereko, V. L.; Morgavi, D. P.; Rode, L. M.; Beauchemin, K. A.; McAllister, T. A. 2000. Effects of fungal enzyme preparations on hydrolysis and subsequent degradation of alfalfa hay fiber by mixed rumen microorganisms in vitro. Animal Feed Science and Technology 88:153-170.

Nussio, L. G.; Campos, F. P. and Lima, M. L. M. 2011. Metabolismo de carboidratos estruturais. p.193-238. In: Nutrição de ruminantes. Berchielli, T. T.; Pires, A. V.; Oliveira, S. G. Funep, Jaboticabal.

Ørskov, E. R. and McDonald, I. 1979. The estimation of protein degradability in the rumen from incubation measurements weighted according to rate of passage. Journal of Agriculture Science 92:499-503.

Poppi, D. P. and McLennan, S. R. 1995. Protein and energy utilization by ruminants at pasture. Journal of Animal Science 73:278-290.

Schofield, P.; Pitt, R. E. and Pell, A. N. 1994. Kinetics of fiber digestion from in vitro gas production. Journal of Animal Science 72:2980-2991

Tavendale, M. H.; Meagher, L. P.; Pacheco, D.; Walker, N.; Attwood, G. T. and Sivajumaran, S. 2005. Methane production from in vitro rumen incubations with Lotus pedunculatus and Megicago sativa, and effects of extractable condensed tannin fractions on methanogenesis. Animal Feed Science and Technology 123124:403-419.

Theodorou, M. K.; Williams, B. A.; Dhanoa, M. S.; McAllan, A. B. and France, J. 1994. A simple gas production method using a pressure transducter to determine the fermentation kinetics of ruminant feeds. Animal Feed Science and Technology 48:185-197.

Tilley, J. M. A. and Terry, R. A. 1963. A two stages technique for the in vitro digestion of forage crops. Grass and Forage Science 18:104-111.

Vadiveloo, J. 1992. Varietal differences in the chemical composition and in vitro digestibility of rice straw. Journal of Agricultural Science 119:27-33.

Vadiveloo, J. 1995. Factors contributing to varietal differences in the nutritive value of rice straw. Animal Feed Science and Technology 54:45-53.

Van Soest, P. J. 1994. Nutrition ecology of ruminant. 2nd ed. Comstock Cornell University Press, Ithaca, NY.

Van Soest, P. J.; Robertson, J. B. and Lewis, B. A. 1991 Methods for dietary fiber, neutral detergent fiber and non-starch polysaccharides in relation to animal nutrition. Journal of Dairy Science 74:3583-3597.

Wanapat, M. and Pimpa, O. 1999. Effect of ruminal $\mathrm{NH}_{3}-\mathrm{N}$ levels on ruminal fermentation, purine derivatives, digestibility and rice straw intake in swamp buffaloes. Asian-Australasian Journal of Animal Science 12:904-907.

Yang, H. E.; Son, Y. S. and Beauchemin, K. A. 2011. Effects of exogenous enzymes on ruminal fermentation and degradability of alfalfa hay and rice straw. Asian-Australasian Journal of Animal Science 24:56-64. 